\title{
17
}

\section{Selecting, Stretching and Missing the Frame: Making Sense of the Cold War in German and Swiss History Classrooms}

\section{Barbara Christophe}

Memory studies present us with two narratives, both of which tend to offer somewhat opposing images of how we should think about collective memory. According to one school of thought, collective memory appears to be strong and powerful, moulding pasts, rather effectively, according to the needs of shifting presents (Hobsbawm and Ranger 1992; Zelizer 1998). According to the second, collective memory is the precarious result of an attempt to square the circle (Assmann 2006). While it has to decouple from the polyphonic memories of individual persons in order to achieve coherence, it also has to tie in with individual memories in order to be accepted as an appropriate and meaningful frame. It is in line with this second narrative that authors place emphasis on conflict and struggle. When talking about collective memory, one must not expect it to be consensual, coherent or stable (Schwartz 2016, 10), they argue. Memory does not primarily result in social cohesion but instead can serve as an object of contestation (Bodnar 1992; Sturken 1997; Sierps 2014) and

\section{B. Christophe $(\bowtie)$}

Georg Eckert Institute for International Textbook Research, Member of the Leibniz Association, Brunswick, Germany e-mail: christophe@gei.de 
fragmentation (Leggewie 2009; Hoskins 2011); it not only clearly orients an individual but also creates ambivalence and inconclusiveness (Ryan 2011; Sturken 1999; Beattie 2008). It does not travel untouched across time and space, but is instead subject to continuous mutation every time it is invoked.

Against the backdrop of these debates, this chapter analyses how teachers and students in a German and a Swiss history classroom 'do' memory (Macgilchrist et al. 2015), when discussing the origins of the Cold War. Conceived of as a meeting place between members of different generations (Menk 2006), the history classroom is studied from the perspective of memory practices. Looked upon from that angle, teachers and students whose formative experiences took place in different historical periods and who have been exposed to different discourses could be expected to recall the past rather differently (Schuman and Scott 1989).

Focusing on the discursive frames applied by both groups, this chapter explores (i) to what extent the emerging patterns of interpretation are shared, contested or simply diverse, (ii) how coherently they connect to culturally shaped frameworks and (iii) how they interact with one another. I will proceed in three steps: I begin by looking into the discourses enacted by the two teachers, then continue to examine how coherently both of them use framing strategies. Finally, I focus on patterns of interaction that evolve between teachers and students in both classrooms. Comparing both teachers, I show that they differ in selecting frames with opposing political implications but converge in stretching and bending these frames in order to integrate all the details they wish to mention. Analysing classroom talk as an exchange between members of different generations, I point out that students often appear to miss the frames their teachers use, at times because they fail to recognise the political and narrative logic behind them and at other times because they tacitly resist them. Translating these empirical findings into a theoretically relevant contribution to memory studies, I argue that misunderstanding and misperception constitute a likely third option when members of different generations remember the past, alongside conflict and consensus. I moreover contend that generational differences in judging the past can be linked to the fading of common-sense assumptions as well as to differences in moral demands. With regard to history teaching, I point out that 
both teachers simultaneously invoke and suppress the political due to how each remembers the Cold War, thus making it considerably more difficult for their students to understand them.

\section{Method}

My analysis draws mainly on two video-recorded lessons on the origin of the Cold War. ${ }^{1}$ In addition, the interpretation of some particularly dense moments of classroom discourse is corroborated by referring back to different types of interviews ${ }^{2}$ conducted with the two teachers, as well as to observational data gathered during ethnographic field work in their respective classrooms. ${ }^{3}$ While I do not aspire to present findings representative of German or Swiss history lessons as a whole, I do depict in detail situated classroom talk that should allow us to better understand what happens when members of different generations interpret a contested past like the Cold War.

Conceptually, this chapter is geared towards frame analysis, which aims at identifying the major cognitive schemata people use to organise experience and give meaning to reality (Goffman 1974). Beyond this rather general definition, my understanding of the concept of the frame is based on three crucial claims. First, I take frames to be a 'configuration of positions' (Lombardo et al. 2009, 11), which are not restricted to cognitive schemata alone but also include normatively loaded bias and assumptions of which people are not aware. Accordingly, I pay close attention to hidden assumptions implied but not explicitly stated when approaching the framing of discourses in the classroom. Second, in line with discourse-based approaches I assume that the frames used by individuals are embedded in socially shared networks of frames, which we shall call frameworks for the sake of clarity (Marx Ferree 2009). This leaves me with the task of identifying culturally influenced interpretations of issues and events within the frames used in the two classrooms. Finally, I believe that frames play a vital role in helping us to make sense of the world by reducing complexity and by pointing our attention to certain factors while bracketing out others. Frames order and link events together into packages. 


\section{Selecting Different Frames}

A first comparison of both lessons quickly reveals that both teachers adhere to surprisingly similar strategies on some levels, while making completely different choices on others. To begin with similarities, both start their lessons with caricatures focusing on the break-up of the AntiHitler Coalition. While the German teacher refers to the famous Swiss drawing, 'Draft of a Memorial to the Victors', which features Roosevelt and Stalin sitting on a horse with two heads pointing in opposite directions, the Swiss teacher employs a caricature of Truman and Stalin on a tandem which then breaks apart into two unicycles heading different ways. Moreover, during the latter part of each lesson, both teachers ask their students to use fragments of the famous speeches given by Truman and Stalin in 1947 to illustrate their initial thoughts on the opposing ideas Americans and Soviets stood for. However, as we shall see, each

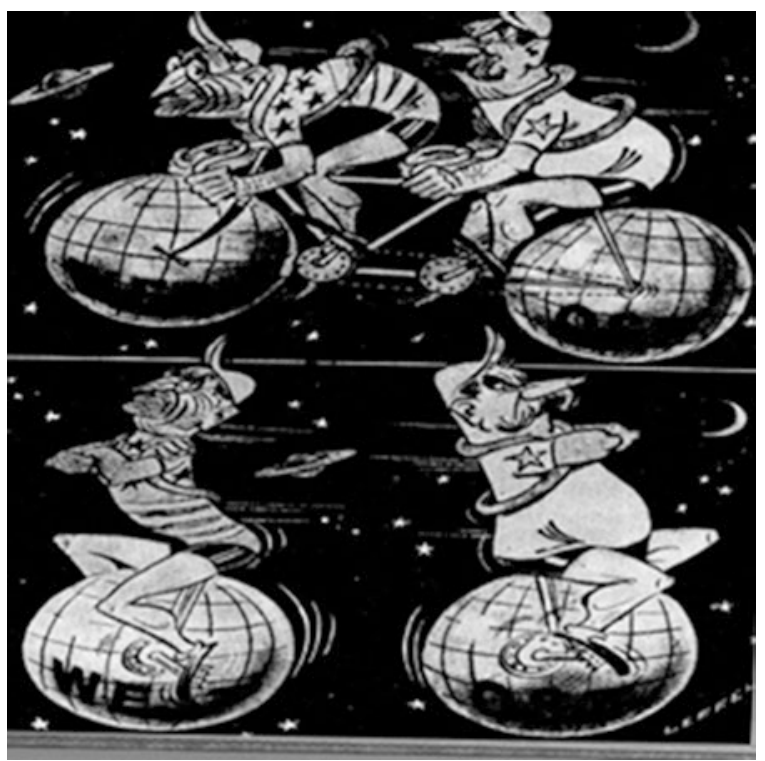

Fig. 17.1 Cartoon entitled 'Tour du Monde: Tandem oder Einrad?' by Jean Leffel. From German textbook: Menschen in Zeit und Raum 9, Edition for Lower Saxony, 113 (Zurich: Schulbuch Verlag plus AG, 2012) 


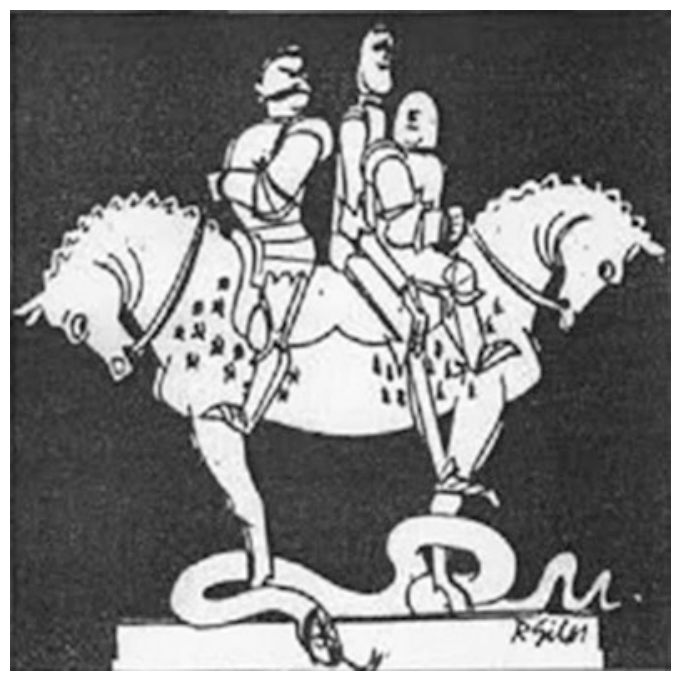

Fig. 17.2 Cartoon entitled 'Entwurf fur ein Siegerdenkmal' or 'Draft of A Memorial to the Victors', published in Schweizer Illustrierte (11 April 1945). Reproduced here from the German textbook: Entdecken und Verstehen 3, Edition for Lower Saxony, 99 (Berlin: Cornelsen, 2010)

teacher contextualises these materials in very different ways, integrating them into opposing frames that support conflicting stories on the origin of the Cold War.

\section{The History Teacher from Germany}

The most prominent feature in the lesson given by the German teacher, here referred to as Ms. Burmeister, is her outspoken anti-Soviet bias. Although she starts the classroom discussion with the cartoon described above, which seems to equally distribute blame for having caused the Cold War between both superpowers, in the remainder of the lesson she places an almost exclusive focus on the Soviets as the main culprits. In order to contextualise the cartoon she draws her students' attention to the famous speech Stalin gave in April 1945. Asking them to read aloud his unambiguous statement that the victorious powers would impose their social systems on all occupied countries as far as their armies advance, she 
evokes the image of an aggressive Soviet Union. Something similar happens in the next phase of the lesson.

\begin{tabular}{|c|c|c|}
\hline & & $\begin{array}{l}\text { where the borders were between the armies after the } \\
\text { Second World War? }\end{array}$ \\
\hline 00:29:00 & s8 & Um, what it looked like, or the occupying forces? \\
\hline 03 & Tfem & $\mathrm{Hm}$ ? \\
\hline :11 & 58 & $\begin{array}{l}\text { Well, what it/ it looked like, or, [...] or a map with the whole } \\
\text { occupying forces and stuff? \#00:29:12-1\# }\end{array}$ \\
\hline $00: 29: 17-$ & Tfem & $\begin{array}{l}\text { With the occupying forces. We have here 'how/ as far as his } \\
\text { armies can reach'. \#00:29:17-4\# }\end{array}$ \\
\hline 00:30:08 & Tfem & $\begin{array}{l}\text { So, now everyone has, no perhaps not. [...] Some are still } \\
\text { flicking through. \#00:30:00-8\# }\end{array}$ \\
\hline 00:30:17 & S4 & When was the cartoon from again? \\
\hline 00:31:18 & Tfem & $\begin{array}{l}\text { April ' } 45 \text {. But not much changed after that. [...] So. How far } \\
\text { did the Soviet [...] zone of occupation reach? [...] Either look } \\
\text { at the map on page } 62 \text { or on page } 92 \text {, there look at map } 4 .\end{array}$ \\
\hline
\end{tabular}

In this scene, we see how the teacher subsequently reframes the task she is giving to her students without reflecting explicitly on the implications brought about by her change of wording. While she initially asks her students to browse the atlas and search for a map that illustrates the borders between the allied powers in 1945, she then suddenly instructs them to look only for the Soviet zone of occupation. In line with this pattern of placing blame on the USSR while remaining silent on the subject of the USA, a large portion of the lesson-34 out of 90 minutes - is dedicated to a presentation which she gives on the role of the Soviets and the Russians, both of which are repeatedly described as being aggressive and backward (Neumann 1999; Macgilchrist 2011; Lawless 2014). She cites the inclusion of Siberia and Central Asia in the Tsarist Empire as an example of Russia's expansionist drive in the nineteenth century. After the Second World War, the USSR is said to have started its 'march towards the west'. ${ }^{4}$ At the same time, according to Ms. Burmeister, Russia never really had any chance to compete with a West which proved superior on all levels. Economically and socially, Russia, she argues, is 'fairly undeveloped', 5 even 'very primitive in terms of social equality'. ${ }^{6}$ A look at the map illustrates 'that there is not very much [there]', particularly in contrast to 'a map of Germany or maybe Great Britain or France'. 7 The arbitrariness of the Russian Tsar, who was not restrained by any law, contrasts sharply with European monarchies which had adopted constitutions by 
the nineteenth century at the latest. In terms of abolishing serfdom, Russia lagged behind by more than 70 years according to Ms. Burmeister. In the end, she describes Russia as defeated, as a country where 'reforms did not come to anything', ${ }^{8}$ where political disputes triggered either assassinations or civil war with 'all members of the population [...] fighting in groups against one another'.'

\section{The History Teacher from Switzerland}

Most of the time, the history teacher from Switzerland, here referred to as Ms. Reger, establishes frames that are completely different to those used by Ms. Burmeister. At the beginning of the lesson, she contrasts the cartoon, which depicts the Cold War as the result of a disrupted relationship, with a film that focuses on the atomic bomb dropped on Japan by the Americans in 1945. Ms. Reger thus draws on a source that portrays Americans not only as having killed thousands of Japanese civilians, but also as enjoying unrivalled military superiority. To ensure that they get the message, Ms. Reger asks her students whether the film they have seen 'connect[s] at all with the cartoon'. ${ }^{10}$ Subtly preparing the ground for the 'right' answer, she raises the question of 'who's got the better seat on the tandem..${ }^{11}$ Bringing home her own conclusion, she then emphasises that Truman, who is riding in the front seat, clearly had the better position given that 'the one in front can steer'.$^{12}$ Undermining the position articulated by the cartoon, she finally encourages the students to reflect on whether the unicycles are the proper size: 'And [...] are the proportions right at the bottom, the two unicycles? Would they be right at that time, straight after the Second World War?'13 For her, it is crystal clear that America 'ha(s) got the upper hand'14 due to its nuclear weapons, a detail which, she points out, is not mentioned at all in the cartoon. Later in the lesson, when she talks about the general situation different countries faced after 1945, she speaks of the USA as 'the number one as a world power $[. .$.$] economically and [. .$.$] of course militarily', { }^{15}$ as 'a power that can pack a punch'. ${ }^{16}$

While she highlights the power disparities between these two rivals and clearly assigns the position of superiority to America, Ms. Reger downplays political or moral differences, resolutely excluding all traditionalist ideas about a morally superior USA or West. This becomes 
particularly apparent during a classroom discussion on the Truman and Zhdanov speeches when she asks students to stage a clash of arguments between the two. Summing up the discussion, she concludes 'both have the same roles probably using the same means' ${ }^{17}$

At the end of the lesson and during a short lecture on Allied policies in occupied Germany, Ms. Reger openly accuses Americans of having cooperated with the same Nazis they fought against in the Second World War.

01:00:52 ${ }^{18}$ Tfem And what then, what happened after that, the rats, or these

Nazis, they were recycled, well, that's how it's put according to, in this, um, book. It was like this, they then, or in the Cold War, there were plenty of uses for them. In Latin America, when people wanted communist rabble-rousers tracked down. And an example is, um, Klaus Barbie, he was the Butcher of Lyon. He was one of those who fled and was recruited by the $\mathrm{CIA}$ in Bolivia and was one of those responsible for tracking down Che Guevara. [Barbie's] past was irrelevant [to the CIA in recruiting him], but the point is, he was tracked down. (2 sec). So this is referred to as recycling.

She bases her talk on a book that investigates how the Nazis fled legal persecution like rats vanishing through thousands of loopholes. ${ }^{19}$ On a purely linguistic level, she persistently neglects to ascribe responsibility. She speaks of the 'plenty of uses' that were made of the Nazis, who were 'recycled', in Latin America where the 'people', i.e. a rather poorly identified historical protagonist, wanted to track down 'communist rabble rousers', apparently with the help of Nazis. However, with the strategically placed example of Klaus Barbie, who despite his criminal past as the 'Butcher of Lyon' was 'recruited' by the American intelligence agency, the CIA, Ms. Reger clearly invites her students to view the USA as the driving force behind these machinations.

\section{Comparison}

By framing the stories they offer to their students quite differently, both teachers show us that competing approaches in Cold War historiography, declared prematurely dead by some, still play a vital role in school history. 
Probably unwillingly, they moreover remind us of the inescapably political nature that characterises representations in general (Hutcheon 2007) and historical accounts in particular (Sturken 1997).

\section{Stretching the Frame}

While the two teachers clearly differ by invoking culturally opposed frames, both of them encounter similar difficulties in integrating all the details they feel should be mentioned. In the end, both stretch and bend their respective frames successfully in order to make them fit the contours of the stories they wish to tell.

\section{The History Teacher from Germany}

In the case of the history teacher from Germany, traditionalist discourse is interrupted in two significant instances. The first occurs when Ms. Burmeister is talking about the historical dynamics that led to the October Revolution in 1917.

00:54:1520_ Tfem In 1917 the military situation and the economic situation in Russia were so catastrophic that Tsar Nicolas II decided, and was forced of course really, to abdicate. So he did. Then there was a [...] government, provisional government they were called, that came to power and attempted to er, the [...] to contain the military situation, which ultimately they were not able to do. They were expected, really, to make peace. And they should have addressed social injustice more, and especially they should have helped the farmers. For example they should have divided up the land. And that didn't happen. [...] And then there was a, er, group, has been for a long time, since the end of the 19th century, we had them in Germany too, Social Democrats. A party that spoke for the workers. And on the (clicks on the next slide) erm. On the Russian side there were those known as the Bolsheviks. It means 'majority group'. They were particularly radical. And they wanted social equality, land redistribution. They were responsible for what was really a putsch in October 1917. 
In this moment Ms. Burmeister speaks in a rather ambivalent manner about the Bolsheviks. On the one hand, she emphasises the shortcomings of their predecessors, i.e. the provisional government which, according to her, failed to address issues of 'social injustice', thus giving ample cause for upheaval. She even portrays the Bolsheviks as the only historical figures who cared for the viable interests of ordinary men and women and promised 'social equality' and 'land distribution', two things which by today's moral standards appear to be just and fair. On the other hand, Ms. Burmeister describes the same Bolsheviks as 'radical' and as having organised 'what was really a putsch', thus connecting them with two words that definitely have negative connotations in German discourses.

Something similar happens when she introduces Karl Marx as the founding father of Soviet communism.

01:04:35 $\quad$ Tfem They advanced that far. [...] All in the name of a system. The system that was behind it, was called, and is called 'Communism'. [...] Can we now? I'll just turn this off. (Turns the computer screen off.) Er, the idea behind it is [...] from Karl Marx in the $19^{\text {th }}$ century: Society is very unequal. Wealth is very unfairly distributed. Decisions about where money should be spent in a nation are too unfairly distributed. That, how the workers have to live and work, how low their wages are, that is simply not fair. It must be changed. [...] Basically those that own things, should no longer own them. That there should be no more industrialists who decide by themselves ' $I$ ' $m$ going to close my firm, or I'm going to produce this and that' but rather it should be under the control of the workers. That is the central idea. [...]

Marxism is not only presented here as an adequate and legitimate response to a number of unpleasant realities in the nineteenth century when wealth was distributed unfairly, workers received appallingly low wages and common sense would lead one to the conclusion that 'it must be changed' - but the measures Marxists would have implemented in the event of their success are actually openly praised. There is no doubt that, to Ms. Burmeister, depriving 'industrialists' of the ability to shut down factories sounds like a good idea. 
Displaying a surprising degree of attraction to the ideas of Marxism, this teacher is actually close to cracking the traditionalist frame to which she usually refers when telling the story of the Cold War. In such moments, Ms. Burmeister engages a strategy aimed at repairing the damage she may have done to the coherence of her account.

\begin{tabular}{|c|c|c|}
\hline $01.02 .20^{22}$ & Tfem & $\begin{array}{l}\text { And the Soviet Union claimed 'We have realised this. We } \\
\text { have done it like this'. [...] It was opposed to for example } \\
\text { (Turns computer screen back on and goes to 'Stalinism' } \\
\text { slide) um, in agriculture the farmers could no longer } \\
\text { decide themselves what, er, they produced, and at what } \\
\text { price and so on. That was all decided for them. In } \\
\text { businesses the workers could not decide what they } \\
\text { produced, and at what prices and so on. It was all set by } \\
\text { the state. [...] But the claim was 'We have abolished } \\
\text { individual decisions, the individual power of } \\
\text { businessmen. We are working for the people'. }\end{array}$ \\
\hline
\end{tabular}

Ms. Burmeister's strategy mainly rests on denying the Bolsheviks the right to present themselves as legitimate heirs to Marx and Marxism. She points out that after 1917 they did quite the opposite of what Marx had once demanded. Instead of letting workers and farmers determine what they were going to produce and how much money they would charge for their products, she argues, the Bolsheviks simply replaced the former industrialists with the state, thus altering close to nothing for working people, who were still subject to decisions taken by others. In Ms. Burmeister's account there thus appears to be a huge gap between the values the Bolsheviks claim to represent and the cruel reality they created.

\section{The History Teacher from Switzerland}

There is only one moment when Ms. Reger is in danger of transgressing the limits of the revisionist discourse she generally employs: when she talks about the position in which the Western states found themselves after 1945. Broadening the perspective and switching from a hitherto exclusive focus on the USA to allow for a quick glance at the circum- 
stances the United Kingdom was facing at that time, she first of all draws her students' attention to the upcoming end of the British Empire. Putting an emphasis on decolonisation as an important historical process, she touches upon an issue which is regularly raised by authors who argue that the Cold War paradigm is a much too narrow one with which to make sense of all the relevant historical trends that took place across the globe after the Second World War (Conelly 2000; Iriye 2013). However, she herself is far from arriving at this conclusion. Quite the reverse, as becomes evident when she appears anxious to bring the Cold War back in to the discussion. She actually tries hard to explain how an admirable goal like decolonisation was achieved morally under the hegemony of the USA, the world power of which she is otherwise critical.

\begin{tabular}{|c|c|c|}
\hline $0: 26: 31^{23}$ & Tfem & $\begin{array}{l}\text { Because, um, in the Atlantic Charter Roosevelt and } \\
\text { Churchill spoke of it, of the right of peoples to self- } \\
\text { determination. And the inhabitants of the colonies, they } \\
\text { were listening carefully, right, and they thought: Yes, } \\
\text { absolutely! Only, they of course hadn't meant it like that, } \\
\text { or that they [would] give up their colonies, but instead } \\
\text { they were thinking of, yes, that the regions occupied by } \\
\text { Germany should be given up. And so now, after the } \\
\text { Second World War, decolonisation began too. }\end{array}$ \\
\hline
\end{tabular}

Ms. Reger mobilises a rather abstract narrative here, according to which events do not necessarily reflect the initial intentions of those who may have caused them but may well be the unintended side-effects of another conscious action. More concretely, she argues that, in setting up The Atlantic Charter and in subscribing to the principle of selfdetermination, Roosevelt and Churchill would primarily have had in mind the European countries formerly occupied by Nazi Germany as beneficiaries of their actions. To Ms. Reger, it is clear that these two leading Western politicians simply failed to anticipate that the same principle could be applied to colonised parts of the world as well. 'Of course they hadn't meant it like that', Ms. Reger says, 'drawing authority from an unspoken premise' (Geertz 1992, 6) by presenting her judgment as a fact that anybody with a clear mind would spontaneously grasp and embrace. 


\section{Comparison}

Both teachers successfully walk the line between stretching and bending the frame while preventing it from breaking. Both appear to have similar reasons to deviate from culturally shared narratives. From the lifestory interviews we conducted with them, we know that in both cases the historical details they could not help but mention, although they have the potential to undermine the coherence of the overall account, are biographically relevant to them. While Ms. Burmeister spent a lot of time reading Marx in circles of politically active students as a young adult, ${ }^{24}$ Ms. Reger had made many trips to postcolonial countries such as Vietnam or Cuba. ${ }^{25}$

Differences between these two educators in dealing with ambivalences mainly pertain to the repair strategies they apply in the process of modifying the frames they have selected. Portraying the USA as a power which by sheer miscalculation happened to be supportive of the noble goal of decolonisation, Ms. Reger largely preserves the picture she has previously drawn within a revisionist frame. At the same time, Ms. Burmeister allows more ambivalences to enter her discourse. While she mostly draws a rather bleak picture of the Soviet Union, she also admits that the Soviet system was based on noble ideas dating back to Marx. Although she reconciles both perspectives by pointing to an implementation gap, she nevertheless also credits the Soviets with good intentions.

\section{Missing the Frame}

As I argue above, frames are culturally shaped cognitive schemata which help us to recognise a 'messy' reality by imposing a structure upon it. Yet, in order to be readable to people, they are also dependent on culturally shaped common-sense assumptions. As soon as these common-sense assumptions are no longer shared socially, frames may be overlooked. This is what we can observe in both classrooms. In some situations, teachers and students talk at cross purposes. They fail to recognise each other's 
frames because they are unable to infer the other's preferred frame from what has been said.

\section{The History Classroom in Germany}

In the German history class we observed, the students were most actively involved during the last phase of the lesson when they were asked to stage a discussion between Americans and Russians, based on their reading of the famous Truman and Zhdanov speeches from 1947. They were split into four groups with each being instructed to identify either with the Soviets or with the Americans. More specifically, they were tasked with deriving images of the 'self' and the Cold War 'other' from the two speeches. However, all groups had considerable difficulty grasping what the teacher viewed as the bottom line of the claims made by both historical parties.

Looking at the two American groups, we came across two striking moments. Generally speaking, much of the pathos in Truman's speech in 1947 was completely lost in the representation offered by the students. While the American president spoke dramatically about two lifestyles opposing each other, contrasting freedom with oppression and promising help to all free nations ready to resist submission, the students spoke rather dryly of the economic and financial support offered by the USA to the free nations. Moreover, in one particularly striking moment, one female student, here referred to as Marie, who was given the task of summing up Truman's accusations against the USSR, misreads the core words. While the American president spoke about his firm commitment 'to support free peoples who are resisting attempted subjugation by armed minorities or by outside pressures', ${ }^{26}$ Marie speaks of 'the subjugation of the armed minorities as a result of external pressure'. ${ }^{27}$ According to her, the Soviets are thus not guilty of having allowed armed minorities to oppress others; rather, they are charged with having subjugated armed minorities. The teacher quickly corrects Marie by drawing attention to how she has replaced 'by' with 'of'. She also offers her own summary according to which the Soviets did not 'really want to create a democracy' but were 'in fact $[. .$.$] doing the opposite and oppressing'. { }^{28}$ Surprisingly, 
and despite the political disparities between the two versions that are brought to the table by the teacher and Marie, the intervention of the former meets with neither resistance nor further enquiries. Obviously, Marie has failed to make sense of the Truman speech, because she had neither enough historical knowledge nor sufficient stereotypical ideas about the Soviets to compensate for her lack of knowledge. The fact that she does not see any reason to defend her version of the story seems to point to either a lack in awareness about the clash of positions she has just contributed to or to an indifference towards history teaching in general and history teaching about the Cold War in particular. In any case, it seems that the history of the Cold War does not hold enough relevance for Marie for her to make significant effort towards an appropriate interpretation (Schwartz 2016).

If we turn to the groups that were set the task of identifying with Zhdanov, things seem initially to go more smoothly. The ease with which the students seem to grasp the logic behind the Soviet position is perhaps somewhat surprising given Ms. Burmeister's extensive othering of Russia and the USSR earlier in the lesson. The students cast in the role of the Soviets counter the altruistic American self-image the other group had difficulty articulating, claiming that all this was in fact only about imperialism and that the Americans 'just want that so that they can be a world power' ${ }^{29}$ In addition, they correctly reconstruct the Soviet self-image by pointing out that they, the Soviets, wanted 'to reintroduce democracy and to act against, er, against American imperialism' ${ }^{30}$ and 'to beat fascism and, er, act in the name of our people'. ${ }^{31}$

However, at one point, the smoothness of the students' identification with the Soviets is interrupted, although it seems unclear what is actually happening in the following situation:

\begin{tabular}{lll}
\hline 00:34:38 $32-4$ & Tfem & $\begin{array}{l}\text { So let's have the opposite-um-version. How does } \\
\text { the Soviet Union present itself? And the } \\
\text { Americans have to respond [...] Go, S13, S7, S18, } \\
\text { now it's your turn. How do you see yourselves? }\end{array}$ \\
& & $\begin{array}{l}\text { S13masc } \\
\text { We want to destroy democracy }\end{array}$ \\
$00: 34: 43$ & Tfem & You want to destroy democracy? \\
$00: 34: 46$ & S13masc & Yes. We want to destroy democracy.
\end{tabular}


00:34:54

Tfem

I think there's a bit of a misunderstanding there, S13. The Soviets wouldn't say that about themselves.

(General restlessness and some laughter.)

00:35:09 S13masc Yes, first we want er, the position, the same economic position as America, that's what we want to achieve.

At first glance, the student who is talking here, whom we henceforth refer to as Markus, seems to start off on the wrong track. Trying to contribute to the construction of the Soviet self-image, he says, 'we want to destroy democracy'. His classmates respond with laughter. They immediately seem to understand that Markus is violating the general rule of the game by vilifying, instead of glorifying, the Soviet self he was told to identify with.

But what has actually happened? Has Markus made a mistake? The ease with which he presents a better, a more accurate alternative soon after the corrective intervention by the teacher sows doubt. This doubt increases if we look at how Markus behaved in the other lessons we observed. To give one telling example: Asked to describe the feelings of school children who were receiving CARE parcels in the aftermath of the Second World War, he responded with open irony to what appears to him to be a ridiculously simple and obvious task. In contrast to the positive responses of his classmates, who even elaborated on the difference between the truly grateful children of that time and themselves as the spoiled youngsters of today, he made a witty comment suggesting that CARE actually stood for 'Calorien-armes-Reste-Essen' (low-calorie leftovers)..$^{33}$

Is something similar happening in the role-play? Maybe Markus is simultaneously exploiting and undermining the role ascribed to him with his strangely inappropriate self-description of the Soviets as democracydestroying monsters? Perhaps he wishes to unveil the hidden transcript of the lesson according to which these Soviets are always the bad guys? Or possibly he is not the slow but the smart pupil who subtly points to the paradox of staging a seemingly open-ended debate between Soviets and Americans after having been told how backward, evil and violent the Soviets were? 
According to this line of thought, Markus acts as a discourse analyst (Macgilchrist et al. 2017) who uncovers the rules of a discourse according to which it is beyond question that the Soviet are the culprits. We cannot prove this interpretation, but looking at all the mishaps and glitches discussed so far, it is clear that the role-play turned out to be full of lapses and misunderstandings.

\section{The History Classroom in Switzerland}

In the Swiss case, the most obvious instance of missing the frame occurred during a classroom discussion on the peculiarities of the situation the Soviet Union faced on the eve of the Cold War. We observed the following exchange between Ms. Reger and two of her most actively engaged students.

\begin{tabular}{|c|c|c|}
\hline $0: 26: 31^{34}$ & Tf & $\begin{array}{l}\text { OK then, so now there's, um, the Soviet Union here ( } 2 \\
\text { sec). Where does the Soviet Union stand, or what is } \\
\text { there to say here about [...] this state at the end of } \\
\text { the war? }(16 \mathrm{sec}) \text { SmA? }\end{array}$ \\
\hline 0:27:08 & SmA (Peter) & $\begin{array}{l}\text { It pulled out, I mean, from this [...] I mean, after the } \\
\text { world [...] you know, after the two world wars it was } \\
\text { [...] it's shown, there's like a conflict, or sort of a } \\
\text { silent conflict between the two ideologies. }\end{array}$ \\
\hline $0: 27: 20$ & Tf & Hmhm, hmhm. \\
\hline $0: 27: 22$ & SmA (Peter) & $\begin{array}{l}\text { And I have the feeling, I mean, America's scared of } \\
\text { this communism thing. }\end{array}$ \\
\hline $0: 27: 26$ & Tf & $\mathrm{Hmhm}$. \\
\hline $0: 27: 27$ & SmA & $\begin{array}{l}\text { ion is making propaganda against } \\
\text { e sort of on two fronts. }\end{array}$ \\
\hline $0: 27: 34$ & Tf & $\begin{array}{l}\text { Yes, exactly, that's what happens now. But actually, to } \\
\text { complete this here, basically: that was the [...] here: } \\
\text { the coalition against Hitler, right? ( } 4 \mathrm{sec}) \text {. At the end } \\
\text { of the war. So we can see that here. That's it, the, } \\
\text { the tandem you can see [...] see in the cartoon }[. . .] \\
\text { And now... yes? SmA? }\end{array}$ \\
\hline $0: 28: 12$ & SmA (Peter) & $\begin{array}{l}\text { Perhaps there's also [...] gaining land [...] Germany } \\
\text { gets divided up. }\end{array}$ \\
\hline $0: 28$ & & That's it. Yes, precisely. \\
\hline $0: 28: 20$ & $\mathrm{Sm}$ & $\begin{array}{l}\text { And }[\ldots] \text { afterwards, after Europe, this, this, um, Iron } \\
\text { Curtain becomes very strongly felt between East and } \\
\text { West. }\end{array}$ \\
\hline
\end{tabular}


Hmhm, hmhm. Exactly. Let's look at the war now... Perhaps you remember the US entering the war or, put a better way, um, the Soviet... the Soviet Union was attacked and the consequence was - was - huge losses [...] millions of victims (4 sec). And in spite of this: where in the ranking - to come back to the ranking - where are, where's the Soviet Union? (4 sec) Yes, um, SmB?

0:29:08 SmB Actually in second place, because it['s] actually still a really, really big military power.

$0: 29: 13 \quad$ Tf

0:29:35 Tf

That's right. (8 sec) Number two. (10 sec)

That's certainly, um, a point. And SmA said it already: Expansion to the west, that's a given, right? $(11 \mathrm{sec})$ 0:29:55 Tf

And someone said that already, it's like this: (If I [could] just a bit [...]) They, I mean, they're winners too, aren't they? And they're winners, they're both winners, but it became clear that communism's an alternative to this liberal, this liberal democracy. Clear as day, that's the alternative. And why shouldn't communism be the best model? With a [...] with communism you can [...], I mean, you can win wars. So here: communism as an alternative form of society.

The first striking thing to be observed in this intense scene is the careful manoeuvring of the student, 'Peter', who is responding to the teacher's introductory question. He starts to talk only after a rather long period of silence where none of his fellow classmates appear to have sufficient prior knowledge on the Soviets to answer the question. Upon closer examination we can clearly see that even Peter is not really sure about the point he wants to make. We see him cautiously probing, withdrawing and offering contradictory stories of how the Soviets have acted while paying close attention to his teacher's reactions.

Initially, he talks about the Soviets pulling out and thus seems to be invoking a revisionist frame according to which the Soviets would be an exhausted and therefore cautious power. Describing the Soviets as being in retreat in the literal sense of moving back from occupied territories, he is, however, referring to incorrect historical facts. Accordingly, Ms. Reger's reactions are hesitant at best. Mumbling a somewhat indeterminate ' $\mathrm{hm}$ ', we see in the video that her face clearly shows disapproval. 
Given her general inclination towards revisionism, she is, in all likelihood, not disapproving of the overall line of thought that the student is offering but rather of his failure to provide convincing proof.

Reading her face correctly, while probably failing to understand the reasons for her lack of enthusiasm, the student intuitively performs a radical turnaround. Without reflecting on the change in his attitude, he starts to speak about the propaganda war the Soviets have been waging against the Americans who, according to him, were fearful of the Soviets he now suddenly describes as representing a threat. Encouraged by a fellow student who is nodding approvingly at him, Peter continues to elaborate more resolutely the traditionalist frame he has easily switched to by talking about the Iron Curtain the Soviets had erected and the territorial gains they had made.

Ironically, the evolving conversation aptly demonstrates that he could not have missed his teacher's preferred frame more clearly. Again, he is misled by Ms. Reger's ambivalent feedback. While Peter seems to take encouragement from the repeated phrases 'yes, exactly', 'yes, precisely', he simultaneously seems to ignore the critique she is raising.

As soon as he has finished his description of the aggressive and expansive Soviets, Ms. Reger begins to give a kind of counter-speech. However, it is only the concessive phrase 'but actually' that reveals her intention to break with what Peter just has said. She then makes two claims, both of which are clearly meant to reintroduce the revisionist frame that Peter referred to at the beginning of this scene and was unable to substantiate with appropriate evidence. Ms. Reger recalls the enormous losses the USSR experienced in the Second World War after they were attacked, and she emphasises how attractive the Soviet Union and the social order it stood for must have been in the eyes of contemporaries who had just seen them winning the war against the Nazis.

There are four interesting insights to be gained so far: Firstly, in order to satisfy his teacher, Peter is ready to alter his account. Secondly, Peter repeatedly misjudges his teacher's preferences. Thirdly, Ms. Reger picks up only on those comments from the classroom talk which fit her preferred frame, without even mentioning any tension between her 
own claims and the claims put forward by students. Finally, her story quickly acquires authoritative status without any resistance. As a result, the meaning of the Cold War is quickly fixed, despite the fact that it had been mutable just a moment before. All participants in the discussion simultaneously collude in rendering invisible the disagreements and misunderstandings that preceded the fixing of meaning.

Another scene from the Swiss classroom shows that, at times, something more fundamental is involved than simply an array of different assumptions about the Cold War and its main participants. The following exchange takes place during the discussion about the cartoon depicting Truman and Stalin riding a tandem.

\begin{tabular}{|c|c|c|}
\hline$: 12: 03^{35}$ & Tf (Reger) & $\begin{array}{l}\text { And, um, }[. . .], \text { what do you think? [...] The top part of } \\
\text { the picture [...] this tandem, who's got the better } \\
\text { seat on the tandem? }(2 \mathrm{sec}) \text { Yes? SfC? }\end{array}$ \\
\hline $0: 12: 18$ & SfC (Anne) & $\begin{array}{l}\text { (Smiling) Yes, it's Stalin. Because he actually has to do, } \\
\text { you know, less work. I mean, he has to do less } \\
\text { pedalling, but he doesn't get to decide [where to go]. }\end{array}$ \\
\hline $0: 12: 23$ & $\operatorname{Tf}(\mathrm{R} \in$ & $\begin{array}{l}\text { Yes, precisely. So you think that the back seat's the } \\
\text { better one? (brief laugh) }\end{array}$ \\
\hline $0: 12$ & $\mathrm{SfC}$ & $\begin{array}{l}\text { (Smiling) Yes, then nobody sees if he doesn't do } \\
\text { anything. I mean, he's working, the one in front, and } \\
\text { the one at the back can put his feet up. }\end{array}$ \\
\hline $0: 12: 34$ & $\operatorname{Tf}(\mathrm{R}$ & $\begin{array}{l}\text { Hmhm. Quite. But on the other hand, as you said, the } \\
\text { one in front can steer. }\end{array}$ \\
\hline $0: 12: 40$ & & $\begin{array}{l}\text { Now, um, what about, um, this film, I mean, what's it } \\
\text { saying? How can we link it in to this [...] cartoon? } \\
\text { SfB? }\end{array}$ \\
\hline
\end{tabular}

Ms. Reger's question concerning which of the two leaders had the better seat on the tandem produces a discord which is not openly addressed. Whereas Anne clearly points to Stalin as the privileged one who could relax in the back seat while letting Truman do all the work, Ms. Reger sees the advantages on the side of the American president who was able to direct the tandem.

At this point, significant differences in value orientation emerge. For the teacher it seems beyond question that what really counts, especially in politics, is having power over others and thus the ability to shape the world according to your ideas. Anne clearly has other priorities. To start 
with, she bases her judgement on her own everyday experience, which seems to tell her that in an age where one is constantly seeking selfenhancement (Ehrenburg 1998), you are well advised to escape additional responsibilities and get as much rest as you can. Such assumptions and the values behind them are clearly at odds with the quintessential logic in many narratives of the Cold War, which is portrayed as a fierce competition between two rival powers, both striving to impose their own social system upon the rest of the world. ${ }^{36}$

\section{Comparison}

At first glance, teachers and students in the two classes seem to adopt opposing stances. However, if we look at structural issues and focus on the interaction between the two sets of protagonists, we discover surprising similarities. While the German teacher clearly articulates traditional, anti-Soviet perspectives, her students show much more scepticism and restraint with regard to the USA. And whereas the Swiss teacher plays the revisionist card, being much more critical towards the USA, students tend to blame the USSR more strongly. Hence, in both cases we see a degree of mismatch between the positions taken by teachers and their students.

Obviously, students do not relate with the same naturalness to the competing ways of framing the Cold War as do the two teachers, who were for many years exposed to discourses surrounding the conflict. As we can see from the example of Ms. Reger in Switzerland, teachers may oppose the discourses they have grown up with and question the common-sense assumptions upon which these are built. However, at the same time, they have apparently deeply internalised the binary oppositions that come with them. None of this seems to be true for the students as members of a younger generation born long after the end of the Cold War.

Some, like Peter from Switzerland, switch frames with astonishing ease when trying to come up with an 'appropriate' story on the USSR. Others, like Marie in Germany, confuse words when trying to summarise the American point of view. Phrasing the same observations in the language of frame analysis, we can state that the two teachers are using Cold War 
frames as a configuration of positions to package beliefs about social stakeholders in more or less coherent parcels. Yet students pick up individual elements while mostly ignoring relationships and connections as the key units of frames (Marx Ferree 2009). While teachers use, recognise and remember those frames as being embedded in social discourses that structured the political universes in which they grew up, the same frames do not seem to have any practically relevant meaning for the students.

\section{Discussion}

Translating the empirical insights I have presented so far into a more general contribution to the fields of memory studies and history didactics, I would like to make the following points.

\section{Neither Resisting Nor Complying: The Mnemonic Weapons of the Weak}

In the introduction to this chapter I briefly touch upon the opposition between two perspectives on social processes of remembering, with one emphasising consensus and the other stressing conflict. Against the backdrop of this controversy, the most intriguing observation we have made in the two history classrooms pertains to patterns of interaction between teachers and students. We do not see them achieving a consensus on how to make sense of the Cold War. But nor do we see them clashing over competing interpretations. Rather, we observe frequent instances of troubled communication when both students and teachers come up with statements that are either irritating or incomprehensible to the other party.

Reflecting on the likely causes for this phenomenon, a typical feature of the history classroom comes to mind. Teaching has often been described as a rather asymmetrical setting (Gies 2004, 172; Pandel 2017, 44). As we know from anthropological research, these kinds of settings encourage neither resistance nor full compliance (Scott 1985). Those who are in a subordinate position are more likely to simulate the acceptance of the 
status quo while simultaneously striving to undermine it. Some scenes in the German classroom can be seen as fitting into this picture. One student in particular seems to play the role of the joker, on the surface unable to deal properly with the tasks assigned to him while actually mocking the whole idea behind the task. His predominantly ironic attitude thus prevents him from either accepting or rejecting the mnemonic frames offered by his teacher. Berthold Molden (2016) has described something intriguingly similar when discussing how many older people in postsocialist Central Eastern Europe simply ignore the hegemonic narratives about a totalitarian regime that had allegedly taken an entire population hostage and subjected it to relentless oppression. As they would not risk waging a fight they could not hope to win, they did not resist official memory frames but simply undermined them by recalling how normally and even happily they had lived under communism. Above all, these frames appear to be fairly powerful, as they resonate with corresponding stories told in the West about the triumph of freedom and democracy.

\section{Fading Common Sense: The Missing Link in the Trans- generational Transmission of Mnemonic Frames}

We can only compare the situation the students in the two history classrooms - and the older Eastern Europeans - face, however, in terms of power asymmetries. They differ dramatically in one crucial respect: While the Eastern Europeans discussed by Molden were contemporaries of the Cold War, our students cannot rely on personal experiences to define their relationships with the frames imposed upon them. As a result, they are indifferent rather than sceptical. Usually, excepting the example above, they do not respond with irony but with dispassionate inattention to the narrative given by their teachers. This attitude contrasts starkly with that of the teachers, who strive to use the frames coherently even in those rare moments when they stretch and bend them. The fact that they are then eager to engage in 'repair strategies' suggests that they must be aware of the strain they are putting on these frames.

Simultaneously, students generally appear to be relatively poor at recognising frames. This is particularly evident when individual stu- 
dents try to please their teachers and ultimately fail. It is as if the teachers have provided the students with a rough sketch, clearly expecting them to be able to complete the picture they themselves have in mind, while the students see only isolated items randomly pinned together with little indication as to how to proceed. At the core of this issue is that the common-sense assumptions the teachers grew up with appear to have faded away or simply lost their relevance to the lives of the young people they are teaching. As we know from discourse analysis (Fairclough 1989), common-sense assumptions play a vital role in helping people to fill the voids inevitably left by each discourse. It is thus those implicated but not explicated common-sense assumptions that assure the comprehensibility of social discourse and ways of framing these discourses.

\section{Speaking Different Moral Languages: The Deep-seated Roots of the Mnemonic Divide}

The interactions in the Swiss classroom especially reveal that students, as members of a post-Cold War generation, not only lack something in comparison to their teachers who constitute the 'Cold War generation', but also possess something peculiar. This was illustrated during the classroom discussion of the cartoon showing Stalin and Truman riding a tandem. As I have argued, perceiving the figure able to take a rest in the back seat as the more privileged in comparison to the figure in the front seat who has to do all the work, students display hierarchies of values that clearly differ from the attitude expressed by their teacher, who takes it for granted that everyone would be eager to steer from the front seat.

To a certain extent, this finding challenges an observation made by the memory researcher James Wertsch (2008), who suggests some useful analytical categories that should help us to make sense of empirical data on the trans-generational transmission of memory. Comparing accounts of the Second World War given by members of different generations in Russia, he introduces a distinction between what he calls specific narra- 
tives on the one hand and schematic narrative templates on the other. While the former transform concrete, temporally situated events into a story, the latter offer 'a generalised narrative form,' 'an underlying pattern', that may be instantiated in many different situations talking about many different events (Wertsch 2008, 56). Based on this distinction, and referring to his empirical research, Wertsch argues that schematic narrative templates have a better chance of surviving generational change than specific narratives, as repeated use has deeply inscribed them into the cultural repertoire of each society.

In the Swiss classroom we observe something slightly different. Apparently, what sets the teacher's accounts of the origin of the Cold War from those of the students are rather general and abstract patterns of sense-making, patterns which delineate what humans can be expected to strive for. We see the two groups speaking different moral languages and thus, perhaps inevitably, failing to understand each other.

We can assume that these different languages are shaped by two primary factors. On the one hand, we might expect generational differences to be at play in such a situation; the teacher belongs to a generation that believes in the possibility of social change through political organisation, whereas the students live in 'cynical, post-hegemonic times' when 'everybody knows [...] that politics is deceit' (Beasley-Murray 2010, ix). Yet, on the other hand, the peculiarities of the school setting, with its rigid and institutionalised roles, are also a significant factor. Charged with steering the learning process, teachers must be constantly aware of their objective to give direction to others and take control of situations. At the same time, performing their 'job' as students (Breidenstein 2006), young people have a tendency to minimise their efforts. Maintaining a certain image among peers may oblige them to disparage any over-achievers and thus avoid being identified with them.

From this perspective and in accordance with a new trend in memory research (Feindt et al. 2014), the differences between the schematic narrative templates articulated by the teacher and those of her students would be perceived as not only expressions of a generational divide but also as the fluid results of the specific situation. 


\section{Being Political Without Admitting It: The Illusion of Mnemonic Hegemony}

Looked upon from the angle of history didactics, the empirical material I have presented seems to speak of the salience of one oft-forgotten aspect: Both teachers I observed reveal themselves to be persons with easily recognisable political beliefs. But although these beliefs clearly determine the selection choices they make as teachers, as well as the judgements they pass, they are not made explicit. The political is thus simultaneously invoked and backgrounded. The teachers are political without admitting to it.

What we are dealing with, then, are arguably not so much the individual attitudes of two teachers but instead deeply ingrained social habits. The settled societies of the Global North seem to have moved beyond mnemonic conflict, at least in the imagination of part of the cultural elite. Open contestation is often perceived to be an exclusive feature of post-conflict settings or of newly (re)emerging nation-states (SindbækAnderson and Törnquist-Plewa 2016). The ease with which the masternarratives of successful democratisation and westernisation have come to dominate public discourse in Germany (Hertfelder 2017) appears to be a case in point, as does the familiar statement that we have moved beyond old controversies when it comes to the Cold War. Certain tendencies in history didactics also seem directed towards putting constraints on what can be contested legitimately. While some authors would agree that students should be introduced to competing frames of interpreting the past, they would simultaneously insist on teaching them the undisputable facts of the past first (Garske 2017). This whole concept seems to be based on the idea that frames and facts exist independently of each other. However, the two lessons I have discussed here suggest that facts and frames are closely interrelated. The frames the two teachers draw on emerge only as a result of their attempts to establish connections between the facts they mention. The facts the teachers rely on are constituted as relevant and part of important historical evidence only by the frames they are meant to support.

Neglecting these insights means neglecting the persistent presence and even the usefulness of conflict between competing historical frames, 
potentially with serious repercussions for both remembering and teaching the past. While Michael Kammen $(1993,13)$ argues that 'memory is more likely to be activated by contestation and amnesia is more likely to be induced by the desire for reconciliation', my analysis shows that the absence of conflict also deprives students of the opportunity to comprehend memory narratives against the background of counter-narratives.

\section{Notes}

1. The German lesson took place on 12 October 2014 in Year 10 of a comprehensive school; the Swiss lesson took place on 13 October 2014 in Year 10 of a grammar school (Gymnasium). The lessons were recorded, transcribed and rendered anonymous by giving code names to persons and places mentioned. I quote them by indicating the file name and the location of the quote in minutes of recording as indicated in the transcription. The quotes I use in the text were translated from German by the author. The original files can be consulted at the Georg Eckert Institute in Braunschweig on the understanding that the privacy rights of the people involved are respected and guaranteed.

2. In 2014 my Swiss colleague Nora Zimmermann and I conducted biographical-narrative interviews and guideline-based interviews on textbook representations with 10 history teachers in Germany and a further 10 in Switzerland. All teachers were born before 1970 and were thus eyewitnesses of the Cold War period themselves. The interviews which were recorded and transcribed are cited by their number, date and the interviewee's country of origin (WG for western Germany, $\mathrm{CH}$ for Switzerland).

3. The field notes are quoted by indicating the date when the lesson took place, the number we assigned to the teacher who gave it and the location.

4. 2014_10_12_Video_T2_WG_B, 00:14:33-2.

5. Ibid. 00:01:16-5.

6. Ibid. 00:01:25-5.

7. Ibid. 00:00:19-9.

8. Ibid. 00:04:02-8.

9. Ibid. 00:09:20-8.

10. 2014_10_13_Video_T1_CH, 0:09:20. 
11. Ibid. 0:12:03.

12. Ibid. 0:12:34.

13. Ibid. $0: 13: 10$

14. Ibid. 0:13:59

15. Ibid. 0:23:24

16. Ibid. 0:24:08

17. Ibid. 0:44:27

18. Ibid.

19. Rena und Thomas Giefer: Die Rattenlinie. Fluchtwege der Nazis. Beltz, Weinheim 1992.

20. 2014_10_12_Video_T2_WG_B

21. Ibid.

22. Ibid.

23. 2014_10_13_Video_T1_CH

24. WG Teacher 2 biographical-narrative interview 2 (3.06.2014)

25. CH Teacher 1 biographical-narrative interview 11 (12.05. 2014)

26. http://avalon.law.yale.edu/20th_century/trudoc.asp (accessed 14 May 2019).

27. 2014_10_12Video_T2_WG_B, 00:37:00-0.

28. 2014_10_12Video_T2_WG_B, 00:37:17-9.

29. 2014_10_12Video_T2_WG_B, 00:34:09-0

30. 2014_10_12Video_T2_WG_B, 00:35:56-9

31. 2014_10_12Video_T2_WG_B; 00:37:22-9

32. 2014_10_12Video_T2_WG_B.

33. 2015_01_07_FN_WG_teacher2.

34. 2014_10_13_Video_T1_CH.

35. Ibid.

36. Observations I made in another history classroom support the assumption that differences between the values taken for granted by teachers and students have learnt to take for granted can contribute to misunderstandings. In 2015 students in a tenth grade class in western Germany were working in pairs for several weeks preparing presentations on Cold War topics. Two girls had just started to look for material they could use to compare popular culture in East and West Germany during the Cold War. Their teacher, who was born in 1950, recommended that they browse the internet to gather information on the case of Udo Lindenberg. Quickly they ascertained that Lindenberg was a West German singersongwriter who tried for a long time to organise a concert in the GDR 
before finally receiving an invitation. Initially, the ruling party, the SED, would not give him a permit because they suspected him of being too critical of authority in general. The two girls had great difficulty understanding why Lindenberg had been so keen to travel to East Germany in the first place. Based on their common-sense knowledge, East Germany was a grey and dull place nobody would have wanted to visit but everybody tried to escape. The teacher, for whom it was natural that citizens of the FRG would want to keep in touch with their co-nationals in the GDR, had a hard time comprehending the confusion the girls felt. Cf. 2015-01-23-FN-WG-teacher3.

\section{Bibliography}

\section{Textbooks Cited}

Menschen in Zeit und Raum 9. 2012. Edition for Lower Saxony. Zürich: Schulbuch Verlag plus AG.

Entdecken und Verstehen 3. 2010. Edition for Lower Saxony. Berlin: Cornelsen.

\section{Further References}

Assmann, Aleida. 2006. Der lange Schatten der Vergangenheit. Erinnerungskultur und Geschichtspolitik. München: C.H. Beck.

Beasley-Murray, Jon. 2010. Posthegemony. Political Theory and Latin America. Minneapolis/London: University of Minnesota Press.

Breidenstein, Georg. 2006. Teilnahme am Unterricht. Ethnographische Studien zum Schülerjob. Wiesbaden: Verlag für Sozialwissenschaften.

Beattie, Andrew H. 2008. Playing Politics with History. The Bundestag Inquiries into East Germany. New York: Berghahn, 2008.

Bodnar, John. 1992. Remaking America: Public Memory, Commemoration and Patriotism in the Twentieth Century. Princeton: Princetown University Press.

Conelly, Matthew. 2000. 'Taking off the Cold War Lens: Visions of NorthSouth Conflict during the Algerian War of Independence'. American Historical Review 105, no. 3: 739-69.

Ehrenburg, Alain. 1998. Fatique d'etre soi. Paris: Odile Jacob. 
Fairclough, Norman. 1989. Language and Power. Essex: Pearson Education Limited.

Feindt, Gregor et al. 2014. 'Entangled Memory: Toward a Third Way in Memory Studies'. History and Theory 53, no. 1: 24-44.

Garske, Lucas. 2017. 'Zwischen Historischem Denken und Basiswissen. Der Streit um das Berlin-Brandenburgische Kerncurriculum als Debatte um das Grundverständnis des Geschichtsunterrichts'. Zeitschrift für die Didaktik der Gesellschaftswissenschaften 8, no. 1: 119-131.

Geertz, Clifford. 1992. 'Common Sense as a Cultural System'. The Antioch Review 50, nos. 1-2: 5-26.

Gies, Horst. 2004. Geschichtsunterricht. Ein Handbuch zur Unterrichtsplanung. Köln/Weimar/Wien: Böhlau.

Goffman, Erving. 1974. Frame Analysis. An Essay on the Organization of Experience. Cambridge: Harvard University Press.

Hertfelder, Thomas. 2017. 'Opfer, Täter, Demokraten. Über das Unbehagen an der Erinnerung und die neue Meistererzählung der Demokratie in Deutschland'. Vierteljahreshefte für Zeitgeschichte 65, no. 3: 365-394.

Hobsbawm, Eric and Ranger, Terence. 1992. The Invention of Tradition. Cambridge/New York: Cambridge University Press.

Hoskins, Andrew. 2011. 'Media, Memory, Metaphor: Remembering and the Connective Turn'. Parallax 17, no. 4: 19-31.

Hutcheon, Linda. 2007. 'The Postmodern in Retrospect and Gone Forever, But Here to Stay: The Legacy of the Postmodern'. In Postmodernism: What Moment? edited by Pelagia Goulimari, 16-18. Manchester: Manchester University Press.

Iriye, Akira. 2013. 'Historicizing the Cold War'. In The Oxford Handbook of the Cold War, edited by Richard H. Immerman and Petra Goedde, 15-31. Oxford: Oxford University Press.

Kammen, Michael. 1993. Mystic Chords of Memory. The Transformation of Tradition in American Culture. New York: Vintage Books.

Lawless, Katerina. 2014. 'Constructing the Other: Construction of Russian Identity in the Discourse of James Bond Films'. Journal of Multicultural Discourses 9, no. 2: 79-97.

Leggewie, Claus. 2009. 'Zur Einleitung: Von der Visualisierung zur Virtualisierung des Erinnerns'. In Erinnerungskultur 2.0: Kommemorative Kommunikation in digitalen Medien, edited by Erik Meyer, 9-28. Frankfurt am Main: Campus. 
Lombardo, Emanuela, Petra Meier and Mieke Verloo. 2009. 'Stretching and Bending Gender Equality. A Discursive Politics Approach'. In The Discursive Politics of Gender Equality: Stretching, Bending and Policymaking, edited by Emanuela Lombardo, Petra Meier and Mieke Verloo. Abingdon/New York: Routledge.

Macgilchrist, Felicitas. 2011. Journalism and the Political: Discursive Tensions in International News Coverage of Russia. Amsterdam: John Benjamins.

Macgilchrist, Felicitas, Johanna Ahlrichs, Patrick Mielke and Roman Richtera. 2017. 'Memory Practices and Colonial Discourse: On Text Trajectories and Lines of Flight'. Critical Discourse Studies 14, no. 4: 341-361.

Macgilchrist, Felicitas, Barbara Christophe and Alexandra Binnenkade. 2015. 'Memory Practices and History Education.' Journal of Educational Media, Memory, and Society 7, no. 2: 1-9.

Marx Ferree, Myra. 2009. 'Inequality, Intersectionality and the Politics of Discourse: Framing Feminist Alliances'. In The Discursive Politics of Gender Equality: Stretching, Bending and Policymaking, edited by Emanuela Lombardo, Petra Meier and Mieke Verloo. Abingdon/New York: Routledge. Menk, Peter. 2006. Unterricht - Was ist das? Eine Einführung in die Didaktik. Norderstedt: Books on Demand.

Molden, Berthold. 2016. 'Resistant Pasts versus Mnemonic Hegemony: On the Power Relations of Collective Memory'. Memory Studies 9, no. 2: 25-142.

Neumann, Iver B. 1999. Uses of the Other. 'The East' in European Identity Formation. Minneapolis: University of Minnesota Press.

Pandel, Hans-Jürgen. 2017. Geschichtsdidaktik. Eine Theorie für die Praxis. Schwalbach: Wochenschau Verlag.

Ryan, Lorraine. 2011. 'Memory, Power and Resistance: The Anatomy of a Tripartite Relationship'. Memory Studies 4, no. 2: 154-189.

Schuman, Howard and Jacqueline Scott. 1989. 'Generations and Collective Memories'. American Sociological Review 54, no. 3: 359-381.

Schwartz, Barry. 2016. 'Rethinking the Concept of Collective Memory'. In Routledge International Handbook of Memory Studies, edited by Anna Lisa Tota and Trever Hagen, 9-20. London/New York: Routledge.

Scott, James C. 1985. Weapons of the Weak. Everyday Forms of Peasant Resistance. New Haven/London: Yale University Press.

Sierps, Aline. 2014. History, Memory and Trans-European Identity. Unifying Divisions. London: Routledge. 
Sindbaek-Andersen, Tea and Barbara Törnquist-Plewa, eds. 2016. Disputed Memories: Emotions and Memory Politics in Central, Eastern and South-Eastern Europe. Berlin/Boston: Walter de Gruyter.

Sturken, Marita. 1997. Tangled Memories: The Vietnam War, the AIDS Epidemic, and the Politics of Remembering. Berkeley: University of California Press.

Sturken, Marita. 1999. 'The Wall, the Screen and the Image: The Vietnam Veterans Memorial'. In The Visual Culture Reader, edited by N. Mirzoeff, 357-70. New York: Routledge.

Wertsch, James V. 2008. 'The Narrative Organization of Collective Memory'. Ethos 36, no. 1: 120-35.

Zanazanian, Paul and Sabrina Moisan. 2012. 'Harmonizing Two of History Teachings Main Functions: Franco-Quebecois History Teachers and their Predisposition to Catering to Narrative Diversity. Education Sciences 2, no. 4: 255-275.

Zelizer, Barbie. 1998. Remembering to Forget. Holocaust Memory through the Camera's Eye. Chicago: University of Chicago Press.

Open Access This chapter is licensed under the terms of the Creative Commons Attribution 4.0 International License (http://creativecommons.org/licenses/ by/4.0/), which permits use, sharing, adaptation, distribution and reproduction in any medium or format, as long as you give appropriate credit to the original author(s) and the source, provide a link to the Creative Commons licence and indicate if changes were made.

The images or other third party material in this chapter are included in the chapter's Creative Commons licence, unless indicated otherwise in a credit line to the material. If material is not included in the chapter's Creative Commons licence and your intended use is not permitted by statutory regulation or exceeds the permitted use, you will need to obtain permission directly from the copyright holder. 